\title{
Optimasi Formula dan Uji Antibakteri Terhadap Staphylococcus aureus dan Propionibacterium acne Pada Sediaan Emulgel Kombinasi Minyak Atsiri Cinnamomum Zeylanicum dan Citrus hystrix dengan Desain Faktorial $\mathbf{2}^{\wedge} \mathbf{2}$

\author{
(Optimization Formula and Antibacterial Activity of Emulgel Preparation
} Containing Combination of Cinnamomum Zeylanicum And Citrus Hystric Essential Oil Against Staphylococcus aureus and Propionibacterium acne Using Factorial Design $2^{\wedge} 2$ Method)

\author{
Amaliyah Dina Anggraeni ${ }^{1}$, Raditya Weka Nugraheni ${ }^{1}$, Uswatun Chasanah ${ }^{1}$, Salma Lutfia \\ Azzahra ${ }^{1}$, Adam Rachmatullah Akbar ${ }^{1}$, Imanda Karir Fanani ${ }^{1}$
}

Jalan Bendungan Sutami 188A, Sumbersari, Kec. Lowokwaru, Kota Malang, Jawa Timur 65145

Email : radityawn@umm.ac.id

\begin{abstract}
Cinnamon and lime essential oils are known as antibacterial activity. It contains citronellol, geraniol, cinnamaldehyde, and Eugenol. This study aims to determine the concentration of combination Cinnamomum zeylanicum and Citrus hystrix essential oils in emulgel preparations as an antibacterial against Staphylococcus aureus and Propionibacterium acnes. Dosage formulation of emulgel made in various concentrations of combinations of C. Zeylanicum And C. Hystric Essential Oil that 0.5: 2 (FI); $0.5: 4$ (FII); $1: 2$ (FIII); 1: 4 (FIV) respectively. Further preparation of the emulgel evaluated physical, chemical characteristics, stability during storage, and antibacterial activity. Factorial design $2^{\wedge} 2$ used to analyze data on the test characteristics of emulgel preparations. The result showed that all formulations have the characteristics of soft, white, and smells of lime and cinnamon. Viscosity, $\mathrm{pH}$, spreadability, freeze-thaw, and real-time temperature stability did not differ significantly. The F3 showed the highest antibacterial activity against Staphylococcus aureus and Propionibacterium acne with a zone of inhibition of $19.10 \mathrm{~mm}$ and $19.10 \mathrm{~mm}$, respectively. Variation of $C$. zeylanicum and $C$. hystrix essential oils had a significant $\mathrm{pH}$ change in the one-month real-time stability test at various temperatures. The antibacterial activity there was no synergistic effect as an antibacterial, which is shown by the absence of interaction between the two active ingredients.
\end{abstract}

Keywords: Cinnamomum zeylanicum, Citrus hystrix, Factorial design, Formulation, Antibacterial

\section{PENDAHULUAN}

Kulit merupakan panca indera sekaligus lapisan pelindung tubuh yang terletak paling luar. Penampilan kulit seseorang biasanya dapat terganggu dengan adanya sentuhan, rangsangan rasa sakit, maupun pengaruh buruk dari luar. Pengaruh tersebut dapat menyebabkan suatu penyakit di kulit. Penyakit yang paling umum diderita masyarakat Indonesia terkait dengan masalah tersebut yaitu jerawat (Lely et al, 2016).

Bakteri penyebab jerawat diantaranya Propionibacterium Acnes, Staphylococus epidermidis dan Staphylococcus aureus (Pelen et al, 2016). Staphylococcus aureus menjadi salah satu bakteri yang menginfeksi kulit dan menyebabkan jerawat. Bakteri ini memiliki suatu protein dan polisakarida yang bersifat antigenik (Dewi, 2013). Obat jerawat yang beredar di pasaran biasanya banyak mengandung Bahan Kimia dengan kadar tinggi yang bisa menyebabkan efek samping yang tidak diinginkan (Silalahi et al, 2016). Masalah resistensi terhadap antibiotik menjadi salah satu masalah serius yang sedang dihadapi oleh masyarakat seluruh dunia. Kayu manis (Cinnamomum zeylanicum) dan Jeruk purut (Citrus hystrix) adalah tumbuhan endemik di kawasan asia tenggara, termasuk Indonesia sehingga dapat mudah dijumpai (Setyabudi., 2015). Berdasarkan hasil penelitian Apriyani et al. (2015) menyatakan bahwa 
terdapat aktivitas antibakteri terhadap P. acnes dengan nilai konsentrasi hambat minimum (KHM) 0,2\% dari minyak kayu manis dengan diameter hambat sebesar $8,43 \mathrm{~mm} \pm 0,023$. Menurut hasil penelitian Kusumawati (2018) menyatakan bahwa minyak atsiri yang terkandung dalam daun jeruk purut mempunyai aktivitas anti jerawat terhadap $P$. acne dengan nilai konsentrasi hambat minimum (KHM) $1 \%$ dari minyak atsiri dengan diameter hambat sebesar $17,36 \mathrm{~mm} \pm 0,116$ yang berarti dalam hasil penelitian tersebut responnya terbilang sedang

Bentuk sediaan gel lebih baik digunakan pada pengobatan jerawat daripada bentuk sediaan krim karena sediaan gel dengan pelarut yang polar lebih mudah dibersihkan dari permukaan kulit setelah pemakaian dan tidak mengandung minyak yang dapat meningkatkan keparahan jerawat (Sasanti et al., 2012). Sehingga, peneliti akan melakukan optimasi formula emulgel kombinasi minyak kayu manis (Cinnamomum zeylanicum) dan minyak daun jeruk purut (Citrus histrix) lalu melakukan analisis menggunakan metode faktorial desain. Selanjutnya dilakukan pengujian terhadap karakteristik fisik sediaan dan uji aktivitas antibakteri pada bakteri Staphylococcus aureus dan Propionibacterium acne.

\section{II.TINJAUAN PUSTAKA}

Kulit merupakan lapisan pelindung tubuh terhadap pengaruh luar, baik pengaruh fisik maupun pengaruh kimia (Pelen, 2016). Menurut Sonny dan Kalangi (2013) lapisan kulit terdiri dari 3 lapisan utama yaitu epidermis, dermis dan hypodermis. Salah satu penyakit pada kulit adalah jerawat. Jerawat menyerang kulit di berbagai area meliputi wajah, dada dan punggung. Jerawat biasa terjadi selama masa remaja, menyerang sekitar $80-90 \%$ remaja di negara barat (Suva et al., 2014).

Resistensi akibat penggunaan bahan kimia untuk mengatasi jerawat menjadi alas an untuk eksplorasi bahan alam sebagai alternative penggantinya. Minyak atsisi kayu manis dan jeruk purut secara empiris telah berkasiat sebagai antibakteri (Apriyani et al, 2015)

Emulgel kombinasi minyak atsiri Cinnamomum zeylanicum dan Citrus hystrix terdiri dari dua fase, yaitu fase besar molekul organik yang terpenetrasi dalam air dalam bentuk gel dan fase kecil minyak emulsi. Adanya fase minyak di dalamnya menyebabkan emulgel lebih unggul dibandingkan dengan sediaan gel sendiri, yakni obat akan melekat cukup lama di kulit dan memiliki daya sebar yang baik, mudah dioleskan serta memberikan rasa nyaman pada kulit (Sari et al., 2016).

\section{III.METODE PENELITIAN}

Penelitian ini menggunakan alat antara lain Cawan petri, mortir dan stamper, alat-alat gelas, $\mathrm{pH}$ meter (oakton), Neraca analitik digital (metler toledo), Viskometer Brookfield (azka laboratorium), Pipet volume (iwaki).

Bahan-bahan penelitian meliputi Minyak atsiri kayu manis, Minyak atsiri jeruk purut, Carboxy polymethylene (Carbomer), Propilenglikol, Polioxyethylene sorbitan monoester (Tween 80), Sorbitan ester (Span 20), Metylparaben, Propylparaben, Trietanolamin (TEA), Minyak jojoba, Aquades, Bakteri Staphylococcus aureus, Propionibacterium acnes yang diperoleh dari Laboratorium Biomedik Program Studi Pendidikan Dokter Fakultas Kedokteran Universitas Muhammadiyah Malang, Klindamisin.

Metode kerja penelitian diuraikan seperti di bawah ini:

\subsection{Pembuatan Sediaan Emulgel}

Pembuatan formulasi emulgel anti-acne kombinasi minyak kayu manis dan minyak daun jeruk purut dibuat seperti table 1. Setiap formula dilakukan replikasi sebanyak tiga kali dengan berat masing-masing sediaan $200 \mathrm{~g}$.

Karbomer ditaburkan pada mortar yang telah terisi aquades setengah dari kebutuhan. Setelah mengembang, diteteskan TEA sampai pH 7. Dibuat fase minyak dengan menambahkan Span 20, nipasol, minyak jojoba dan BHT. Diaduk campuran hingga larut dan homogen. Kemudian dibuat fase air dengan cara mencampurkan tween 80, prolipenglikol, nipagin dan Na-edta. Aduk hingga larut, masukan sisa aquades kebutuhan total, aduk kembali sampai homogen. Fase minyak dicampurkan ke dalam fase air sedikit demi sedikit pada mortar, digerus dengan konstan hingga terbentuk massa emulsi. Dimasukan 
bahan aktif minyak kayu manis dan minyak daun jeruk purut, diaduk hingga homogen. Setelah emulsi terbentuk, dimasukan emulsi ke dalam gel yang sudah mengembang, diaduk hingga terbentuk massa emulgel yang homogen.

Tabel 3.1 Formula emulgel kombinasi minyak kayu manis dan minyak daun jeruk purut

\begin{tabular}{|c|c|c|c|c|c|c|}
\hline Bahan & Fungsi & $\begin{array}{l}\text { Control } \\
\text { negative }\end{array}$ & $\begin{array}{l}\text { F1 } \\
(\% \\
)\end{array}$ & $\begin{array}{l}\mathrm{F} 2 \\
(\% \\
)\end{array}$ & $\begin{array}{l}\mathrm{F} 3 \\
(\% \\
)\end{array}$ & $\begin{array}{l}\mathrm{F} 4 \\
(\% \\
)\end{array}$ \\
\hline $\begin{array}{l}\text { Minyak } \\
\text { kayu } \\
\text { manis }\end{array}$ & $\begin{array}{l}\text { Bahan } \\
\text { aktif }\end{array}$ & - & 0,5 & 0,5 & 1 & 1 \\
\hline $\begin{array}{l}\text { Minyak } \\
\text { daun } \\
\text { jeruk } \\
\text { purut }\end{array}$ & $\begin{array}{l}\text { Bahan } \\
\text { aktif }\end{array}$ & - & 2 & 4 & 2 & 4 \\
\hline $\begin{array}{l}\text { Carbox } \\
\text { y } \\
\text { polyme } \\
\text { thylene } \\
\text { (Carbo } \\
\text { mer) }\end{array}$ & $\begin{array}{l}\text { Basis } \\
\text { gel }\end{array}$ & 1 & 1 & 1 & 1 & 1 \\
\hline $\begin{array}{l}\text { Trietan } \\
\text { olamin } \\
\text { (TEA) }\end{array}$ & $\begin{array}{l}\text { Alkaliz } \\
\text { ing } \\
\text { agent }\end{array}$ & $\begin{array}{l}\text { qs ad } \\
\text { netral }\end{array}$ & $\begin{array}{l}\text { qs } \\
\text { ad } \\
\text { net } \\
\text { ral }\end{array}$ & $\begin{array}{l}\text { qs } \\
\text { ad } \\
\text { net } \\
\text { ral }\end{array}$ & $\begin{array}{l}\text { qs } \\
\text { ad } \\
\text { net } \\
\text { ral }\end{array}$ & $\begin{array}{l}\text { qs } \\
\text { ad } \\
\text { net } \\
\text { ral }\end{array}$ \\
\hline $\begin{array}{l}\text { Propile } \\
\text { nglikol }\end{array}$ & $\begin{array}{l}\text { Enhanc } \\
\text { her }\end{array}$ & 5 & 5 & 5 & 5 & 5 \\
\hline $\begin{array}{l}\text { Polioxy } \\
\text { ethylen } \\
\text { e } \\
\text { sorbita } \\
\text { n } \\
\text { monoes } \\
\text { ter } \\
\text { (Tween } \\
80 \text { ) }\end{array}$ & $\begin{array}{l}\text { Emulg } \\
\text { ator }\end{array}$ & 1,09 & $\begin{array}{l}1,0 \\
9\end{array}$ & $\begin{array}{l}1,0 \\
9\end{array}$ & $\begin{array}{l}1,0 \\
9\end{array}$ & $\begin{array}{l}1,0 \\
9\end{array}$ \\
\hline $\begin{array}{l}\text { Sorbita } \\
\mathrm{n} \text { ester } \\
\text { (Span } \\
20 \text { ) }\end{array}$ & $\begin{array}{l}\text { Emulg } \\
\text { ator }\end{array}$ & 3,91 & $\begin{array}{l}3,9 \\
1\end{array}$ & $\begin{array}{l}3,9 \\
1\end{array}$ & $\begin{array}{l}3,9 \\
1\end{array}$ & $\begin{array}{l}3,9 \\
1\end{array}$ \\
\hline $\begin{array}{l}\text { Metylp } \\
\text { araben }\end{array}$ & $\begin{array}{l}\text { Penga } \\
\text { wet }\end{array}$ & 0,1 & 0,1 & 0,1 & 0,1 & 0,1 \\
\hline $\begin{array}{l}\text { Propylp } \\
\text { araben }\end{array}$ & $\begin{array}{l}\text { Penga } \\
\text { wet }\end{array}$ & 0,1 & 0,1 & 0,1 & 0,1 & 0,1 \\
\hline
\end{tabular}

\begin{tabular}{|c|c|c|c|c|c|c|}
\hline $\begin{array}{l}\text { Minyak } \\
\text { jojoba }\end{array}$ & $\begin{array}{l}\text { Emolie } \\
\mathrm{nt}\end{array}$ & 2 & 2 & 2 & 2 & 2 \\
\hline $\begin{array}{l}\text { Butylat } \\
\text { ed } \\
\text { Hydrox } \\
\text { ytoluen } \\
\text { e } \\
\text { (BHT) }\end{array}$ & $\begin{array}{l}\text { Antiok } \\
\text { sidan }\end{array}$ & 0,1 & 0,1 & 0,1 & 0,1 & 0,1 \\
\hline $\begin{array}{l}\text { Sodium } \\
\text { ethylen } \\
\text { ediami } \\
\text { netetraa } \\
\text { cetic } \\
\text { acid } \\
\text { (Na- } \\
\text { EDTA) }\end{array}$ & $\begin{array}{l}\text { Chelati } \\
\text { ng } \\
\text { agent }\end{array}$ & 0,1 & 0,1 & 0,1 & 0,1 & 0,1 \\
\hline $\begin{array}{l}\text { Aquade } \\
\mathrm{s}\end{array}$ & Pelarut & Ad 100 & $\begin{array}{l}\text { Ad } \\
10 \\
0\end{array}$ & $\begin{array}{l}\text { Ad } \\
10 \\
0\end{array}$ & $\begin{array}{l}\text { Ad } \\
10 \\
0\end{array}$ & $\begin{array}{l}\text { Ad } \\
10 \\
0\end{array}$ \\
\hline
\end{tabular}

\subsection{Evaluasi Sediaan Emulgel}

Evaluasi sediaan emulgel meliputi evaluasi fisik antara lain organoleptic, homogenitas, viskositas, tipe emulsi, pengukuran $\mathrm{pH}$, uji daya sebar, uji freeze Thaw dan uji stabilitas. Pada uji organoleptic Dilakukan pengamatan terhadap warna, bau, pertumbuhan jamur untuk sedaan emulgel. Sedangkan homogenitas sediaan dilakukan dengan menimbang 0,1 gram sediaan kemudian dioleskan secara merata dan tipis pada kaca arloji. Gel harus menunjukkan susunan yang homogen dan tidak terlihat adanya bintik-bintik (Elmitra dan Rikohimah, 2018).

Pengukuran viskositas sediaan gel diukur menggunakan alat viskometer Brookfield. Pertama 150 gram gel dimasukkan kedalam beaker glass (Zulfa et al., 2018). Kemudian dipasang spindel nomer 4, lalu spindel diturunkan sampai batas spindel tercelup pada sediaan gel. Kemudian dinyalakan alat dengan menekan tombol on. Kecepatan alat diatur mulai 0,3 rpm. Dari masingmasing pengukuran dengan perbedaan kecepatan rpm dibaca skala hingga jarum merah yang bergerak stabil (Rabima dan Marshall, 2017).

Tipe emulsi dilakukan dengan cara memberikan 1 tetes larutan metilen biru pada 0,1 gram krim, 
kemudian diamati penyebaran warna metilen biru dalam sediaan dibawah mikroskop. $\mathrm{pH}$ sediaan diuukur dengan alat $\mathrm{pH}$ meter (Erawati et al., 2015).

Uji daya sebar dilakukan dengan mengambil sebanyak 0,5 gram sediaan emulgel kemudian diletakkan ditengah-tengah kaca bulat dan ditutup kaca lain yang telah ditimbang terlebih dahulu dan dibiarkan selama 1 menit. Gel yang menyebar diukur diameternya dengan mengambil panjang rata-rata diameter dari beberapa sisi. Diatasnya ditambah beban 50 gram, dibiarkan 1 menit dan diukur diameter sebarnya. Diteruskan penambahan beban tiap kali sebesar 50 gram hingga 250 gram, setelah 1 menit diukur hingga diperoleh diameter yang cukup untuk melihat pengaruh beban terhadap perubahan diameter sebar gel (Elmitra dan Rikohimah, 2018).

Uji freeze thaw dilakukan untuk melihat stabilitas fisik krim setelah disimpan selama 2 minggu pada suhu yang berbeda yaitu $4^{\circ} \mathrm{C}$ dan $40^{\circ} \mathrm{C}$. Penyimpanan dilakukan dalam enam siklus dan satu siklus berlangsung selama dua hari pada masingmasing pada masing-masing suhu. Krim ditimbang \pm 2 gram, dimasukkan ke dalam beberapa vial (Hamsinah et al., 2019). Uji stabilitas fisik dilakukan dengan penyimpanan pada suhu $40 \pm 2{ }^{\circ} \mathrm{C}, 28 \pm 2{ }^{\circ} \mathrm{C}$ dan $4 \pm 2{ }^{\circ} \mathrm{C}$ selama 1 bulan. Pengamatan organoleptis dan pengukuran $\mathrm{pH}$ dilakukan pada hari ke-1 dan 30 (Praptiwi et al., 2014).

\subsection{Uji Aktivitas antibakteri}

\section{Pembuatan media Muller Hinton}

Media MHA ditimbang sebanyak 12,16gram kemudian dimasukkan ke dalam Erlenmeyer 500 $\mathrm{mL}$, dilarutkan dengan $320 \mathrm{~mL}$ aquades steril, dan dipanaskan sampai mendidih. MHA yang telah dibuat ditutup kertas aluminium dan disterilkan dalam autoklaf 15 menit suhu $121^{\circ}$ C.Media dituangkan ke dalam cawan petri yang akan digunakan, ditunggu hingga padat. kemudian cawan petri dibungkus dan disimpan dilemari es. Media dapat digunakan langsung pada saat akan inokulasi.

\section{Inokulasi bakteri}

Bakteri uji diambil dengan jarum ose steril, lalu ditanamkan pada media agar miring dengan cara menggores. Selanjutnya diinkubasi dalam inkubator pada suhu $37^{\circ} \mathrm{C}$ selama 24 jam. Perlakuan yang sama dilakukan pada setiap jenis bakteri uji (Silalahi et al., 2016)

\section{Pembuatan Mc farland}

Larutan $\mathrm{H} 2 \mathrm{SO} 4 \quad 0,36 \mathrm{~N}$ sebanyak $99,5 \mathrm{ml}$ dicampurkan dengan larutan $\mathrm{BaCl}_{2} \cdot 2 \mathrm{H}_{2} \mathrm{O} \quad 1,175 \%$ sebanyak $0,5 \mathrm{ml}$ dalam erlenmeyer. Kemudian dikocok sampai terbentuk larutan yang keruh. Kekeruhan ini dipakai sebagai standar kekeruhan suspensi bakteri uji (Fatimawati, 2012).

Pembuatan suspense bakteri Staphylococcus aureus dan Propionibacterium acnes

Bakteri uji pada media agar miring diambil dengan kawat ose steril lalu disuspensikan kedalam tabung yang berisi $2 \mathrm{ml}$ larutan $\mathrm{NaCl} 0,9 \%$ hingga diperoleh kekeruhan yang sama dengan standar kekeruhan larutan Mc. Farland (Kumesan et al, 2013).

Tabel 3.2 Standar kekeruhan Mc. Farland

\begin{tabular}{|l|l|l|l|l|}
\hline $\mathrm{T}$ & $\begin{array}{l}\mathrm{CFU} \\
\left(10^{8} / \mathrm{ml}\right)\end{array}$ & $\begin{array}{l}1 \% \\
\mathrm{BaCl}_{2}(\mathrm{ml})\end{array}$ & \begin{tabular}{l}
$\mathrm{H}_{2} \mathrm{SO}_{4}(\mathrm{ml})$ \\
\hline
\end{tabular} & Abs \\
\hline 0,5 & 150 & 0,05 & 9,95 & 0,132 \\
\hline 1 & 300 & 0,1 & 9,9 & 0,257 \\
\hline 2 & 600 & 0,2 & 9,8 & 0,451 \\
\hline 3 & 900 & 0,3 & 9,7 & 0,582 \\
\hline
\end{tabular}

Sumber : (Sesilia et al, 2017)

\section{Uji daya hambat bakteri}

Sumuran yang sudah dibuat pada media pengujian diteteskan larutan uji yaitu emulgel yang dilarutkan dalam aquades steril sebanyak 2 gr dalam $2 \mathrm{~mL}$ aquades sebanyak $50 \quad 1$ menggunakan mikropipet, kemudian diinkubasi dalam inkubator pada suhu $37^{\circ} \mathrm{C}$ selama 24 jam, setelah itu dilihat ada tidaknya zona hambat yang terbentuk. Jika ada, diukur diameter daerah hambatan di sekitar pencadang menggunakan jangka sorong dengan cara mengukur secara horizontal dan vertikal kemudian hasil yang didapat dikurangi diameter sumuran $6 \mathrm{~mm}$ (Nisa, 2013).

\subsection{Analisis Data}

Analisis data uji karakteristik fisik sediaan menggunakan one-way anova. dengan derajat kepercayaan $\alpha=0,05$. Jika $\alpha<$ dari derajat 
kemaknaan 0,05 menunjukkan ada perbedaan yang bermakna, sehingga dilanjutkan dengan uji Honestly Significant Different (HSD) untuk mengetahui data mana yang berbeda. Analisis data uji stabilitas metode real time dan freeze thaw sediaan dilakukan menggunakan Paired Sample T Test.

Analisa data dalam penelitian ini juga dilakukan dengan metode desain faktorial. Metode tersebut digunakan untuk menghasilkan persamaan desain faktorial untuk masing-masing respon kadar kombinasi minyak dan sifat karaketristik dan aktivitas antibakteri emulgel. Masing-masing persamaan desain faktorial tesebut dianalisis signifikansinya untuk mengetahui apakah persamaan tersebut dapat digunakan untuk memprediksi kadar kombinasi minyak dan sifat antibakteri emulgel. Berdasarkan pertimbangan signifikansi pengaruh dari masing-masing faktor terhadap respon kadar kombinasi minyak dan sifat antibakteri yang diamati, dilakukan prediksi hasil respon menggunakan software Minitab 19.0 untuk memperoleh komposisi optimum minyak kayu manis dan minyak daun jeruk purut.

\section{HASIL DAN PEMBAHASAN}

Pemeriksaan organoleptis sediaan emulgel menunjukkan hasil bahwa keempat formula pada semua replikasi memiliki tekstur yang lembut, beraroma khas dengan warna putih. Uji homogenitas juga menunjukkan pada keempat formula dapat tercampur atau homogen.

Konsistensi sediaan emulgel tidak boleh terlalu keras dan terlalu encer. Hasil pengujian viskositas pada penelitian ini menunjukkan formula I $(108333,33 \pm 16921,39 \mathrm{cPs})$, formula II $(96000 \pm$ $19078,78 \mathrm{cPs})$, formula III $(123666,67 \pm 49692,39$ cPs), formula IV $(119333,33 \pm 50292,48 \quad \mathrm{cPs})$. Berdasarkan persyaratan SNI 16-4399-1996 tentang rentang viskositas sediaan emulgel yang memenuhi syarat yaitu 2000-50000 cPs, 4 formula sediaan emulgel yang dihasilkan tidak memenuhi persyaratan viskositas sediaan emulgel. Dengan factorial desain diketahui bahwa kadar minyak kayu manis dan jeruk purut tidak memiliki pengaruh yang signifikan terhadap viskositas sediaan emulgel kombinasi minyak atsiri Cinnamomum zeylanicum dan daun Citrus hystrix. Dari hasil uji analisis statistik menggunakan Minitab Main Effect Screener pada Gambar 4.1 Dapat diketahui bahwa semakin tinggi kadar minyak kayu manis maka efek viskositasnya semakin tinggi sedangkan kadar minyak jeruk yang semakin tinggi akan menurunkan viskositas sediaan tersebut. Dari hasil uji analisis statistik menggunakan Minitab Interaction Plot pada gambar 4.2 Dapat diketahui bahwa tidak terjadi interaksi antara minyak kayu manis dan minyak jeruk purut terhadap viskositas sediaan.

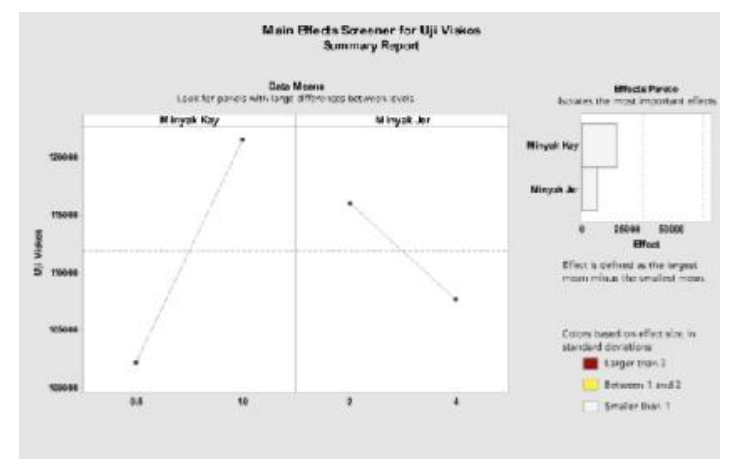

Gambar 4.1 Hasil Main Effects Screener Uji Viskositas Formula I, Formula II, Formula III dan Formula IV Sediaan Emulgel Antiacne Kombinasi Minyak Atsiri Cinnamomum zeylanicum dan Daun Citrus hystrix DC

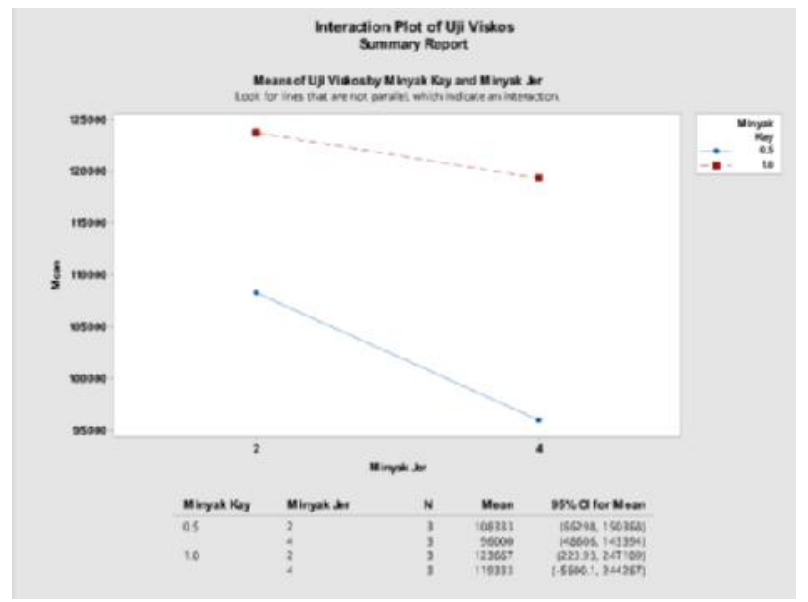

Gambar 4.2 Hasil Interaction Plot Uji Viskositas Formula I, Formula II, Formula III dan Formula IV Sediaan Emulgel Antiacne Kombinasi Minyak Atsiri Cinnamomum zeylanicum dan Daun Citrus hystrix DC

Uji emulsi menunjukkan keempat formula emulgel termasuk emulsi tipe M/A. Hasil pengukuran rerata $\mathrm{pH}$ sediaan emulgel untuk $\mathrm{F}$ 1, F2, $\mathrm{F} 3$, dan $\mathrm{F} 4$ berturut-turut adalah $6,63 \pm 0,03 ; 6,65 \pm 0,18 ; \quad 6,49 \pm 0,08 ; \quad$ dan $6,60 \pm 0,01$. hasil uji analisis statistik menggunakan Minitab Factorial Design memberikan informasi bahwa kadar minyak kayu manis dan minyak jeruk purut tidak berpengaruh secara signifikan terhadap harga pH sediaan emulgel antiacne kombinasi minyak kayu 
manis dan minyak daun jeruk purut. Semakin tinggi kadar minyak kayu manis maka harga $\mathrm{pH}$ semakin rendah sedangkan kadar minyak jeruk yang semakin tinggi akan meningkatkan harga $\mathrm{pH}$ sediaan tersebut. interaksi antara minyak kayu manis dan minyak jeruk purut dapat terjadi tetapi tidak memberikan hasil bermakna (Gambar 4.3).

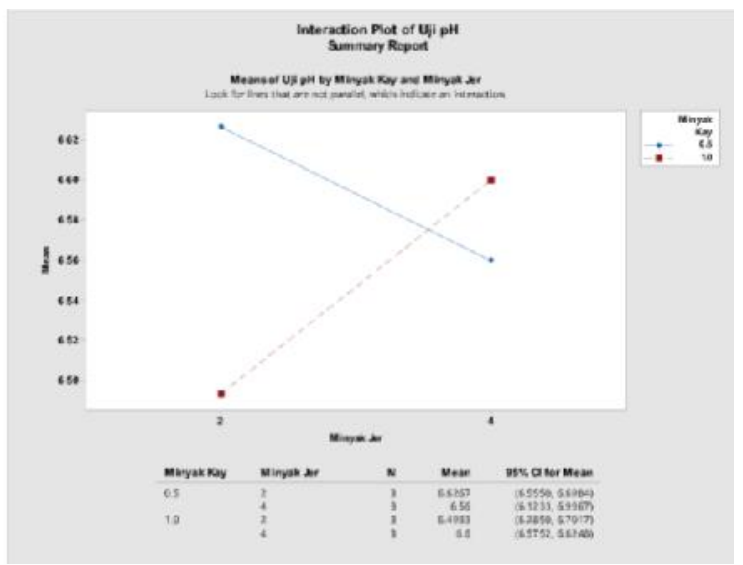

Gambar 4.3 Hasil Interaction Plot Uji pH Formula I, Formula II, Formula III dan Formula IV Sediaan Emulgel Antiacne Kombinasi Minyak Atsiri Cinnamomum zeylanicum dan Daun Citrus hystrix DC

Daya sebar sediaan semisolid yang baik adalah 5-7 $\mathrm{cm}$ sehingga nyaman saat digunakan. 4 formula sediaan emulgel yang dihasilkan tidak memenuhi persyaratan daya sebar. Analisis yang dilakukan dengan desain faktorial menunjukkan bahwakadar dua bahan aktif yang digunakan tidak berpengaruh signifikan terhadap daya sebar sediaan emulgel. Semakin tinggi kadar minyak kayu manis dan minyak jeruk maka daya sebarnya semakin tinggi. Tidak terjadi interaksi antara minyak kayu manis dan minyak jeruk purut terhadap daya sebar sediaan emulgel.

Uji Freeze Thaw sediaan emulgel kombinasi minyak kayu manis dan minyak daun jeruk purut stabil dan tak terjadi pemisahan fase. Untuk $\mathrm{pH}$ didapatkan rerata \pm SD yaitu formula $1(6,53 \pm 0,30)$, formula $2(6,27 \pm 0,21)$, formula $3(6,22 \pm 0,15)$, formula $4(6,33 \pm 0,11)$. Hasil $\mathrm{pH}$ mengalami penurunan dari $\mathrm{pH}$ sediaan awal, dan juga $\mathrm{pH}$ tersebut masih berada dalam rentang $\mathrm{pH}$ sediaan menurut SNI 16-4399-1996, yaitu 4,5-8,0. One-Way Anova dilakukan untuk mengetahui adanya pengaruh kadar minyak kayu manis dan minyak jeruk purut dengan derajat kepercayaan $\alpha=0,05$ diperoleh nilai $p$ $(0.231)>\alpha(0,05)$. Hasil tersebut menunjukkan bahwa terdapat perbedaan $\mathrm{pH}$ yang bermakna pada sediaan emulgel. Uji paired sample test didapatkan perbedaan yang bermakna dengan nilai $\mathrm{p}(0,000)$. Selanjutnya dilakukan uji yang terakhir yaitu uji stabilitas sediaan emulgel yang dilakukan pada hari ke-1 dan hari ke-30 pada berbagai suhu $\left(4 \pm 2^{\circ} \mathrm{C}\right.$, $30 \pm 2^{\circ} \mathrm{C}, 40 \pm 2^{\circ} \mathrm{C}$ ). Didapatkan warna putih dan bau khas jeruk purut dan kayu manis dan tidak terjadi pemisahan fase untuk semua formula dan replikasinya. Setelah sediaan disimpan selama 1 bulan. Terjadi penurunan $\mathrm{pH}$ pada sediaan akan tetapi masih masuk dalam rentang $\mathrm{pH}$ sediaan yang aman. Analisis statistika One-Way Anova dengan derajat kepercayaan $\alpha=0,05$ diperoleh nilai $\mathrm{p}(0.231)$ $>\alpha(0,05)$ sehingga tidak terdapat perbedaan $\mathrm{pH}$ yang bermakna pada sediaan emulgel. Uji paired sample test didapatkan perbedaan yang bermakna dengan nilai $\mathrm{p}(0,000)$.

Uji antibakteri pada Staphylococcus aureus dan Propionibacterium acne Emulgel Kombinasi Minyak Kayu Manis dan Minyak daun jeruk purut dapat dilihat pada tabel III

Tabel 4.1 Diameter Zona Hambat Hasil Uji Antibakteri

\begin{tabular}{|l|l|l|}
\hline Parameter & $\begin{array}{l}\text { S. } \\
\text { aureus } \\
(\mathrm{nm})\end{array}$ & P. acne $(\mathrm{nm})$ \\
\hline Kontrol Positif & 25,1 & 21,89 \\
\hline Kontrol negatif & 9,2 & 7,55 \\
\hline Formula I & 14,4 & 12,89 \\
\hline Formula II & 15,3 & 9,78 \\
\hline Formula III & 19,1 & 14,22 \\
\hline Formula IV & 18,4 & 17,66 \\
\hline
\end{tabular}

Kriteria terhadap penilaian antibakteri yaitu sangat kuat (zona hambat $>20 \mathrm{~mm}$ ), kuat (zona hambat $10-20 \mathrm{~mm}$ ), sedang (zona hambat 5-10 mm) dan lemah (zona hambat $<5 \mathrm{~mm}$ ) (Saraung, 2018). Berdasarkan kriteria diatas maka dapat dikatakan bahwa daya hambat antibakteri termasuk dalam kelompok kuat sehingga sediaan emulgel dapat digunakan sebagai antibakteri dari jerawat.

\section{V.PENUTUP}

Variasi kadar Cinnamomum zeylanicum 0,5\% dan $1 \%$ dan daun Citrus hystrix DC 2\% dan $4 \%$ tidak berpengaruh signifikan terhadap karakteristik fisik dan stabilitas freeze thaw sediaan 
emulgel. Namun, Hasil uji stabilitas real time 1 bulan pada berbagai suhu terjadi perubahan $\mathrm{pH}$ yang bermakna. Sedangkan pengaruh variasi kadar kombinasi bahan aktif minyak atsiri kayu manis dan minyak atsiri daun jeruk purut dalam sediaan emulgel terhadap daya hambat bakteri Staphylococcus aureus dan Propionibacterium acne tidak memiliki efek sinergis sebagai anti bakteri yang ditunjukan dengan tidak adanya interaksi antara kedua bahan aktif.

\section{DAFTAR PUSTAKA}

[1] Lely, N., Firdiawan, A., \& Martha, S. (2016). Efektivitas Antibakteri Minyak Atsiri Rimpang Jahe Merah (Zingiber officinale var . Rubrum) Terhadap Bakteri Jerawat. Scientia, 6(1), 44-49. https://doi.org/2087-5045

[2] Pelen, S., Wullur, A., \& Citraningtyas, G. (2016). Formulasi Sediaan Gel Antijerawat Minyak Atsiri Kulit Batang Kayu Manis ( Cinnamomum Burmanii ) Dan Uji Aktivitas Terhadap Bakteri Staphylococcus aureus. 5(4), 136-144.

[3] Dewi, A. K. (2013). Isolasi , Identifikasi dan Uji Sensitivitas Staphylococcus aureus terhadap Amoxicillin dari Sampel Susu Kambing Peranakan Ettawa ( PE ) Penderita. Sain Veteriner, 31(2), 138150.

[4] Silalahi, Y. C. E., Sari, I., Siregar, S., Sinaga, D. R., Matari, M., Studi, P., ... Mutiara, S. (2016). Pengujian Antibakteri Bedak Dingin Herbal Mahkota Dewa Terhadap Bakteri Penyebab Jerawat. 1(1), 3743.

[5] Setyabudi, C., Tanda, S., Santosa, W. I., \& Soetaredjo, F. E. (2015). Studi in Ekstrak Kulit Jeruk Purut untuk Aplikasi Terapi Diabetes Melitus. Jurnal Ilmiah Widya Teknik, 14(1), 15-19.

[6] Sasanti, t.j., wibowo, ms., fidrianny, i. dan caroline, s. (2012). formulasi gel ekstrak air teh hijau dan penentuan aktivitas antibakterinya terhadap propionibacterium acnes. school of pharmacy itb, gedung labtek vii, bandung (http:// www.doc88.com/p-074807880615.html, diakses 17 september 2019).

[7] Zulfa, E., Liya, L., \& Mimik, M. (2018). Formulasi Sediaan Krim Daun Binahong (Anredera cordifolia ( Ten .) Steenis ): Kajian Karakteristik Fisika Kimia dan Uji Iritasi Kulit. Inovasi Teknik Kimia, 3(1), 46-52.
[8] Rabima, \& Marshall. (2017). Uji Stabilitas Formulasi Sediaan Krim Antioksidan Ekstrak Etanol 70\% Dari Biji Melinjo (Gnetum gnemon L.). Indonesia Natural Research Pharmaceutical Journal Universitas, 2(1), 107-121

[9] Erawati, E., Pratiwi, D., \& Zaky, M. (2015). Formulation Development and Evaluation of Physical Preparation Cream. 3(1). [10] Sarumaha, Kardiaman Lius. (2014).

[10] Elmitra, \& Rikohimah, S. E. (2018). Jurnal Katalisator. 3(2), 153-161.

[11] Hamsinah, H., Darijanto, S. D., \& Mauluddin, R. (2019). Uji Stabilitas Krim Tabir Surya Serbuk Rumput Laut (Eucheuma cottonii. Doty). Jurnal Fitofarmaka Indonesia, 3(2), 155-158

[12] Praptiwi, P., Iskandarsyah, I., \& Kuncari, E. (2014). Evaluasi, Uji Stabilitas Fisik dan Sineresis Sediaan Gel yang Mengandung Minoksidil, Apigenin dan Perasan Herba Seledri (Apium Graveolens L.). Indonesian Bulletin of Health Research, 42(4), 213222

[13] Fatimawati., W. I. W. M. D. A. (2012). Uji Aktivitas Antibakteri Ekstrak Etanol Daun Mayana (Coleus atropurpureus [L] Benth) Terhadap Staphylococcus aureus, Escherichia coli dan Pseudomonas Aeruginosa Secara In-Vitro. Bioedusiana, 2(3), 13-21.

[14] Arista, Y., Kumesan, N., Yamlean, P. V. Y., \& Supriati, H. S. (2013). Formulasi Dan Uji Aktivitas Gel Antijerawat Ekstrak Umbi Bakung (Crinum Asiaticum L.) Terhadap Bakteri Staphylococcus Aureus Secara in Vitro. PHARMACON Jurnal Ilmiah Farmasi - UNSRAT, 2(02), 2302-2493.

[15] Sesilia Rante Pakadang, Rusmin, N. A. (2017). Uji Aktifitas Perasan Bawang Putih (Allium sativum) Asal Kabupaten Gowa Terhadap Pertumbuhan Candida Albicans.

[16] Nisa, U., Darjono,A. 2013.”Analisis Minyak Atsiri Serai (Cymbopogon citratus) sebagai Alternatif Bahan Irigasi Saluran Akar Gigi dengan Menghambat Pertumbuhan Enterococcus faecalis". Majalah Sultan Agung. 59 (125).

[17] Saraung, V., Yamlean, P. V, \& Citraningtyas, G. 2018. Formulasi Gel Ekstrak Etanol Daun Tapak Kuda ( Ipomoea pescaprae L .) dan Uji Aktivitas Antibakteri Terhadap StapHylococcus aureus. Program Studi Farmasi FMIPA, UNSRAT Manado. 
[18] Sonny, J. R., \& Kalangi. (2013). Histofisiologi Kulit. Jurnal Biomedik, 5(3), 12- 20

[19] Suva, M. A., Patel, A. M., Sharma, N., Bhattacharya, C., \& Mangi, R. K. (2014). A Brief Review on Acne Vulgaris: Pathogenesis, Diagnosis and Treatment. Research \& Reviews: Journal of Pharmacology, 4(3), 1-12

[20] Apriyani, Y. M., Priani, S.E., Gadri Amila (2015). Aktivitas Antibakteri Minyak Batang Kayu
Manis (Cinnamomum burmannii Nees Ex BI) terhadap Bakteri Propinibacterium acnes.Prosiding Penelitian SPeSIA., 248-353

[21] Sari, D. K., Sugihartini, N., \& Yuwono, T. (2016). Evaluasi Uji Iritasi Dan Uji Sifat Fisik Sediaan Emulgel Minyak Atsiri Bunga Cengkeh (Syzigium Aromaticum). Pharmaciana, 5(2), 115120 